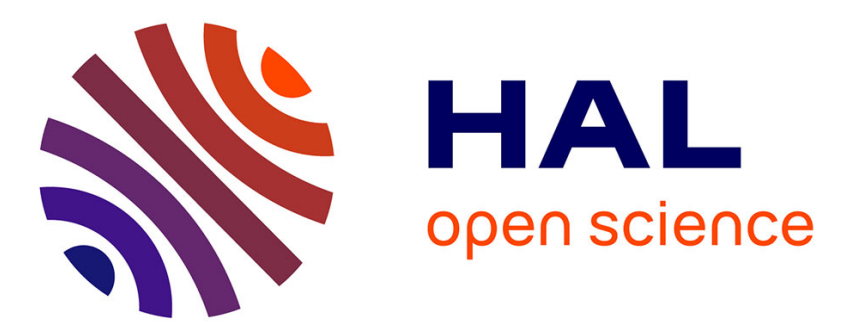

\title{
Insect immunity-effects of factors produced by a nematobacterial complex on immunocompetent cells $(1)$.
}

Carlos Ribeiro, Bernard Duvic, P Oliveira, Alain Givaudan, Filipa Palha, Nelson Simoes, Michel Brehélin

\section{- To cite this version:}

Carlos Ribeiro, Bernard Duvic, P Oliveira, Alain Givaudan, Filipa Palha, et al.. Insect immunityeffects of factors produced by a nematobacterial complex on immunocompetent cells(1).. Journal of Insect Physiology, 1999, 45 (7), pp.677-685. 10.1016/S0022-1910(99)00043-8 . hal-01190075

\section{HAL Id: hal-01190075 \\ https://hal.science/hal-01190075}

Submitted on 1 Sep 2015

HAL is a multi-disciplinary open access archive for the deposit and dissemination of scientific research documents, whether they are published or not. The documents may come from teaching and research institutions in France or abroad, or from public or private research centers.
L'archive ouverte pluridisciplinaire HAL, est destinée au dépôt et à la diffusion de documents scientifiques de niveau recherche, publiés ou non, émanant des établissements d'enseignement et de recherche français ou étrangers, des laboratoires publics ou privés. 


\title{
Insect immunity-effects of factors produced by a nematobacterial complex on immunocompetent cells ${ }^{1}$
}

\author{
Carlos Ribeiro a , Bernard Duvic ${ }^{\text {b }}$, Paulo Oliveira ${ }^{\text {a }}$, Alain Givaudan ${ }^{\text {b }}$, Filipa Palha ${ }^{\text {a }}$, \\ Nelson Simoes ${ }^{a}$, Michel Brehélin ${ }^{\text {b,* }}$ \\ a Departamento de Biologia, Universidade dos Açores, 9502, Ponta Delgada, Portugal \\ ${ }^{\mathrm{b}}$ Laboratoire de Pathologie Comparée INRA-CNRS (URA 2209) Pl. E. Bataillon, 34095, Montpellier, France
}

Received 11 August 1998; accepted 12 October 1998

\begin{abstract}
During in vitro incubations, the nematobacterial complex Steinernema carpocapsae-Xenorhabdus nematophilus produces different factors having toxic activities in vitro towards haemocytes, the insect cells responsible for cellular immune defense reactions. Among others, two effects were evident on haemocyte monolayers; one of them was a cytotoxic activity while the other was an unsticking effect. The factors responsible for cytotoxic activity and unsticking effect, were separated from each other by a single chromatography on anion exchange column. These two effects on haemocytes were lost after heat treatment at $57^{\circ} \mathrm{C}$ for $1 \mathrm{~h}$ and $45^{\circ} \mathrm{C}$ for $30 \mathrm{~min}$, respectively. Both factors were recovered after dialysis in a $10^{4} \mathrm{Da}$ cut off membrane. The cytotoxic activity was susceptible to proteases. Cytotoxic and unsticking factors did not show any lipase or lecithinase activity but the unsticking factor had protease activity. Lipopolysaccharides, purified from the bacteria harvested after incubation of the complex, did not have cytotoxic or unsticking effect on the insect cells in vitro. () 1999 Elsevier Science Ltd. All rights reserved.
\end{abstract}

Keywords: Haemocyte; Cytotoxin; Bacteria; Steinernema carpocapsae; Xenorhabdus nematophilus

\section{Introduction}

The study of insect immune reactions is important in at least three points of view. First, the phylogenic aspect led us to a better understanding on how these reactions have been acquired by metazoans, especially the reactions of innate immunity (Hoffmann et al., 1996). Second, from a medical point of view, different molecules working in insect immune reactions could be used for human or animal health. Last, disturbance of insect defense reactions could be used in biological control of insect vectors or other pests. This is why numerous laboratories have engaged in large scale studies on insect defense reactions. As in mammals (Brunham et al., 1993), successful insect pathogens are able to avoid or

\footnotetext{
* Corresponding author. Tel.: +334671446 72; fax: +3346714 4679.

E-mail address: brehelin@crit.univ-montp2.fr (M. Brehélin)

1 Carlos Ribeiro and Bernard Duvic contributed equally to this study.
}

to depress host defenses. Therefore, one means available to further understand insect immunity is to study its depression by parasites or pathogens such as the nematobacterial complex Steinernema carpocapsae-Xenorhabdus nematophilus.

The nematode S. carpocapsae (Steinernematidae) and its associated bacteria $X$. nematophilus (Enterobacteriaceae) are pathogenic for various insect species (Laumond et al., 1979) and are used in biological control. The basis of their infectivity is poorly understood. In vivo studies have shown that toxins are secreted by both the axenic nematodes (Boemare et al., 1982; Burman, 1982) and/or their bacterial symbiote (Dunphy and Webster, 1984; Bowen et al., 1998, in an other genus of bacteria Photorhabdus luminescens). Other in vivo studies concluded that insect immunocompetent cells, the haemocytes, are hit by virulence factors (reviewed in Akhurst and Dunphy, 1993) and this would be, at least in part, the reason for the immunodepressive effects observed in the infected insects. In a previous paper (Ribeiro et al., 1996) we described the haemocytes of the lepidopteran Mythimna unipuncta (Lepidoptera, 
Noctuidae), a natural host of the nematobacterial complex, and their role in defense reactions in vivo and in vitro. We have shown that monolayers of haemocytes can be used to study the effects of different molecules on these cells in vitro. To study further the immunodepressive effect of the parasite on the cellular defense reactions of insects, we sought to clarify the possible effect on haemocyte monolayers of factors produced by the nematobacterial complex. We show that these cells are one of the targets of at least two different molecules produced by this complex and that the effects of the two molecules on haemocytes are different from each other.

\section{Materials and methods}

\subsection{Biological species}

M. unipuncta larvae were reared on simplified artificial medium (Vieira and Pintureau, 1994), at $23^{\circ} \mathrm{C}$, $65 \pm 5 \%$ relative humidity, and a photoperiod of $16: 8 \mathrm{~h}$ (L:D). In these conditions the 6th (last) larval instar, used throughout this study, lasted 8 days. Galleria mellonella (Lepidoptera, Pyralidae) larvae were reared on pollen and wax at $27^{\circ} \mathrm{C}, 65 \%$ relative humidity, in the dark. Holoxenic nematodes were collected from infested $\mathrm{Gal}$ leria larvae. Germ free nematodes were reared on artificial medium as described by Boemare et al. (1983) after axenization of the eggs in $10 \%$ sodium hypochlorite.

The strain F1 of Xenorhabdus nematophilus and the Breton strain of Steinernema carpocapsae were used throughout this study.

\subsection{Incubation of axenic nematodes, bacteria or nematobacterial complex}

The nematobacterial incubation medium was composed of Tyrode solution (purchased by Sigma) supplemented with $20 \%$ of serum from G. mellonella. The final medium, adjusted to $\mathrm{pH} 6.8$, was centrifuged at $30000 \mathrm{~g}$ for 3 hours and sterilized by filtration through $0.22 \mu \mathrm{m}$ filters. For G. mellonella serum preparation, haemolymph was collected by puncturing a proleg of chilled fifth instar larvae, kept at room temperature for 2 hours and centrifuged at $12000 \mathrm{~g}$ for $20 \mathrm{~min}$. The supernatant (=serum) was stored at $-80^{\circ} \mathrm{C}$ until use.

Before incubation, holoxenic infective stage nematodes were surface disinfected for $15 \mathrm{~min}$ in a $1 \%$ solution of methyl benzethonium chloride then washed twice in sterile water. Axenic nematodes were only washed twice in sterile water. Incubations of axenic or holoxenic nematodes $(10 \mathrm{ml}$ incubation medium in 100 $\mathrm{ml}$ flasks with about 3 nematodes per $\mu \mathrm{l}$ ) lasted up to 96 hours at $23^{\circ} \mathrm{C}$ and $80 \mathrm{rpm}$. During incubation, the infective L3 larvae of holoxenic nematodes, turned to L4 and adults. In axenic rearing the different developmental stages and adults were present together. So it was not possible to check for the transformation of infective L3 larvae into L4 and adults during incubation time. After incubation, the nematodes were removed from the medium by centrifugation at $200 \mathrm{~g}$ for 3 min then the supernatant was centrifuged at $30000 \mathrm{~g}$ for $20 \mathrm{~min}$, filtered on $0.22 \mu \mathrm{m}$ and stored at $4^{\circ} \mathrm{C}$. This is the starting sample that is the Nematobacterial Incubation Medium (=NIM). Throughout the incubation, controls were performed to check for the presence of bacteria other than $X$. nematophilus (the symbiont of the nematode $S$. carpocapsae), using the Nutrient Bromothymol Blue Agar medium (Akhurst, 1980), Nutrient Broth and Nutritive Agar (Boemare and Akhurst, 1988). In one series of experiments, the bacteria present in the medium after $48 \mathrm{~h}$ incubation were harvested, pelleted and the pellets were washed three times in PBS. The last washing solution was tested for absence of cytotoxic or unsticking activity (see below). The washed bacteria were incubated for $36 \mathrm{~h}$ in Tyrode supplemented with Galleria serum. Then the bacteria were pelleted, the supernatant was sterilized by filtration and tested for activities on haemocytes. The pellet of bacteria was used for LPS extraction.

As control, sterile native medium was incubated in the same conditions but in absence of any nematode or bacteria (control medium: CM).

\subsection{Extraction of lipopolysaccharides (LPS)}

The method of Ni Eidhin and Mouton (1993) was used because it produces a good yield of LPS without SDS or other cytotoxic compounds. Briefly the bacteria were lyophilized, mixed with deionised water and placed in a boiling water bath for $15 \mathrm{~min}$. The cellular debris were removed by centrifugation, the supernatant treated with proteinase $\mathrm{K}\left(1 \mathrm{~h}\right.$ at $\left.60^{\circ} \mathrm{C}\right)$ and placed in a boiling water bath for $10 \mathrm{~min}$ and lyophilised.

\subsection{Haemocyte monolayers and test for cytotoxic activity (CyA)}

Chilled 2 day old fifth instar larvae of M. unipuncta were surface disinfected with a solution of ethanolchloroform (v/v) before collection of haemolymph in test tubes filled with sterile anticoagulant buffer (Mead et al., 1986: $62 \mathrm{mM} \mathrm{NaCl}, 100 \mathrm{mM}$ glucose, $10 \mathrm{mM}$ EDTA, $30 \mathrm{mM}$ trisodium citrate, $26 \mathrm{mM}$ citric acid). Approximately one volume of hemolymph was collected in 5 volumes of the buffer. After centrifugation (1000g for $30 \mathrm{sec})$ the haemocyte pellet was rinsed in phosphate buffer saline (PBS, Biomérieux, France: $140 \mathrm{mM} \mathrm{NaCl}$, $2 \mathrm{mM} \mathrm{KCl}, 0.9 \mathrm{mM} \mathrm{CaCl}_{2}, 0.5 \mathrm{mM} \mathrm{MgCl}, 8 \mathrm{mM}$ $\mathrm{Na}_{2} \mathrm{HPO}_{4}, 1.5 \mathrm{mM} \mathrm{KH_{2 }} \mathrm{PO}_{4}$ ) and resuspended in the same saline. $20 \mu \mathrm{l}$ of haemocyte suspension were layered on heat sterilized $\left(220^{\circ} \mathrm{C}\right.$ for 2 hours $)$ glass coverslips. 
All operations were performed at $4{ }^{\circ} \mathrm{C}$. Haemocytes were allowed to adhere on glass for $10 \mathrm{~min}$ in a wet chamber at room temperature then gently rinsed with PBS before use as monolayers.

In tests for cytotoxic activity, excess PBS was pipeted off the coverslip, replaced by $20 \mu \mathrm{l}$ of the solution under study and monolayers were incubated in a wet chamber at $23^{\circ} \mathrm{C}$. Then haemocyte mortality was checked by adding $2 \mu \mathrm{l}$ of Trypan Blue dye (0.04\% in PBS) and 5 min more incubation. In these conditions, incubations lasted for different times (up to 2 hours) and at different dilutions (Tables 1 and 3 ) of the solutions in test. In a series of experiments, haemocytes were rinsed with $1 \mathrm{ml}$ of PBS before addition of Trypan Blue. In another series of experiments, LPS $(20 \mu \mathrm{g} / \mathrm{ml}$ or 40000 endotoxin units) from the serotypes 026:B6, 055:B5, 0127:B8 and 0111:B4 of Echerichia coli, purchased by Sigma, were added to the solutions in test. In a final series of experiments, a solution of LPS extracted from bacteria issuing from incubation of the nematobacterial complex, was tested (final concentration 40000 endotoxin units).

For test of the fractions of chromatography, see below.

\subsection{Test for unsticking effect (UnA)}

Haemocyte monolayers were incubated with one of the solutions in test as above, without rinsing the coverslips. Before observation they were inverted over slides with a central hole ( $2 \mathrm{~mm}$ deep) filled with $0.04 \%$ Trypan blue in PBS and incubated 5 min more. The percentage of haemocytes present on the bottom of the well was calculated from the total number of haemocytes, estimated by light microscopy.

\subsection{Chromatography}

For anion exchange chromatography, the starting sample was desalted with a PD10 column equilibrated with

Table 1

Cytotoxicity of nematobacterial complex incubation medium (NIM) in function of dilution in PBS

\begin{tabular}{ll}
\hline NIM dilutions & Total haemocyte mortality $(\%)$ \\
\hline $1 / 2$ & 100 \\
$1 / 4$ & 100 \\
$1 / 8$ & 100 \\
$1 / 16$ & $89.6 \pm 5.9$ \\
$1 / 32$ & $45.0 \pm 20.6$ \\
$1 / 64$ & $17.6 \pm 12.5$ \\
$1 / 128$ & $<2$ \\
$1 / 256$ & $<2$ \\
Control $^{\mathrm{b}}$ & $<2$ \\
\hline
\end{tabular}

a Mean \pm standard deviation; $\mathrm{n}=30$ insects in three experiments. Incubation time : $1 \mathrm{hr}$.

b Sterile medium incubated at $23^{\circ} \mathrm{C}$ for $48 \mathrm{~h}$, in absence of nematode and bacteria (dilution 1:1 in PBS). phosphate buffer (PB: $10 \mathrm{mM}, \mathrm{pH} 8.0$ ) and then injected onto a Mono Q column equilibrated with same buffer, using an FPLC system (Pharmacia). Bound proteins were eluted with a $\mathrm{NaCl}$ gradient $(20 \mathrm{mM} / \mathrm{min})$ from 0 $0.5 \mathrm{M}$ at a flow rate of $1 \mathrm{ml} / \mathrm{min}$ and $1 \mathrm{ml}$ fractions were collected. Before checking for activity on haemocyte monolayers or for enzymatic activity, aliquots of fractions were diluted in various ratio in PBS. The activity of each chromatographic fraction was compared to the former fraction and the following one.

\subsection{Tests for enzymatic activities}

Protease, lipase and lecithinase were checked in different samples (CM, NIM and different fractions of chromatography).

For protease activity, $85 \mu \mathrm{l}$ of a $2 \%$ solution of azocasein in phosphate buffer (100 mM, pH 7.3) was used as substrate. Fifty $\mu 1$ of each solution to be tested were incubated for 3 hours at $37^{\circ} \mathrm{C}$. Proteins were then precipitated in $10 \%$ trichloroacetic acid and centrifuged at $10000 \mathrm{~g}$ for $10 \mathrm{~min}$. The supernatant was added to $700 \mu \mathrm{l}$ of $\mathrm{NaOH} 1 \mathrm{M}$, and absorbance was recorded at $440 \mathrm{~nm}$.

For lipase activity, $20 \mu \mathrm{l}$ of each sample were spot inoculated on nutrient agar containing $0.01 \%$ calcium chloride and $1 \%$ Tween 20 or Tween 40 (v/v) (Sierra, 1957). Incubation lasted for 5 days at $28^{\circ} \mathrm{C}$. Lipolysis was detected by appearance of a precipitate in agar.

For lecithinase activity, $20 \mu \mathrm{l}$ of each sample were spot inoculated on nutrient agar containing lecithin purified from egg yolk (Sigma) and incubated for $48 \mathrm{~h}$ at $28^{\circ} \mathrm{C}$. Lecithin was first dissolved in $95 \%$ ethanol $(10 \mathrm{~g} / \mathrm{l})$, and $1 \%$ of this solution was incorporated into nutrient agar at $45^{\circ} \mathrm{C}$ (Boemare et al., 1997). Lecithinase activity was indicated by an opaque zone.

\subsection{Resistance of CyA and UnA to physical factors and protease}

For dialysis, $5 \mathrm{ml}$ bags with $10^{4}$ cut off membrane were used and dialysis lasted for a maximum of 24 hours against one liter of PBS.

Resistance to temperature was tested after incubation for $30 \mathrm{~min}$ or 1 hour, of the fractions at different temperatures from $35^{\circ} \mathrm{C}$ to $100^{\circ} \mathrm{C}$. Temperature of the sample was adjusted to $22^{\circ} \mathrm{C}$ before to test for the activity.

For action of trypsin, fractions in test were incubated with a solution of trypsin (final concentration $4.10^{-6} \mathrm{M}$ ) at $\mathrm{pH} 7.7$ and $37^{\circ} \mathrm{C}$ up to 1 hour.

\subsection{Test for LPS}

Presence of LPS in the different fractions was checked using the Limulus test purchased from Sigma, according to the protocol of the manufacturer. This test was also 
used to evaluate the activity of LPS extracted from bacteria of the nematobacterial complex.

\section{Results}

\subsection{Evidence for cytotoxic activity and unsticking activity}

In a first series of experiments, haemocyte monolayers were observed after 1 hour incubation with the medium in which holoxenic nematodes were incubated (NIM). In these experiments, there was no rinsing of the haemocyte monolayers before observation in light microscopy. Almost all haemocytes appeared as swollen cells filled with trypan blue, some of them floating in the buffer. In the control medium, haemocytes were strongly adherent to the coverslips and cells stained with trypan blue were less than $2 \%$ of the total. In a second series of experiments the monolayers were observed after incubation with NIM and rinsing of the coverslips. The haemocytes appeared as lysed cells as above but were much less numerous per surface unit. So we decided to check for two different effects: an evident lysis of the cells and a possible unsticking effect induced by the medium after incubation with the nematobacterial complex.

With this prospect, we tried to separate the molecules in the incubation medium, which could generate these two different effects. Ion exchange was preferred to gel filtration because it induces a lower dilution of the recovered factors in the fractions of chromatography. After chromatography of the Nematobacterial Incubation Medium (NIM) on anion exchange column, cytolysis and unsticking of haemocytes on monolayers were found in two separate fractions (Fig. 1) eluted at 180 mmolar $\mathrm{NaCl}$ for the cytotoxic activity and at 460 mmolar $\mathrm{NaCl}$ for the unsticking effect.

\subsection{Production of the unsticking and cytotoxic factors}

The maximum production of UnA and CyA was reached at 48 hours incubation of the nematobacterial complex. In these conditions we regularly observed $100 \%$ lysis of haemocytes after dilution of the medium up to $1 / 8$ in PBS (Table 1). In all these experiments, controls showed that $X$. nematophilus was the major, if not the sole, bacteria species present in the medium after incubation with the holoxenic nematodes.

After $36 \mathrm{~h}$ cultivation of the bacteria issuing from nematobacterial incubation (see materials and methods), a strong cytotoxic activity was recovered. The unsticking activity of the medium incubated with axenic nematodes was less than that of the nematobacterial incubation medium while that of the washed bacterial cells alone was even less. For instance, in a series of experiments, the maximum dilution for unsticking effect was $1 / 16$ for nematobacterial complex whereas it was $1 / 8$ for axenic nematodes and only $1 / 2$ for bacteria. The cytotoxic activity was never recovered in the medium after incubation of axenic nematodes.

The cytotoxic and unsticking effects were absent in the native control medium as well as in all the fractions obtained after chromatography of this CM achieved in the same conditions as for chromatography of NIM.

\subsection{Unsticking of the cells of monolayers}

When haemocytes were incubated in PBS on slides, they rapidly spread and took characteristic shapes with extended lamellipodia for Plasmatocytes and numerous short filopodia for granular haemocytes (Ribeiro et al., 1996). Haemocytes showed the same shapes after incubation with fractions preceding or immediately following the UnA ones in MonoQ chromatography (Fig. 2a). When chromatographic fractions (diluted $1 / 2$ in PBS)

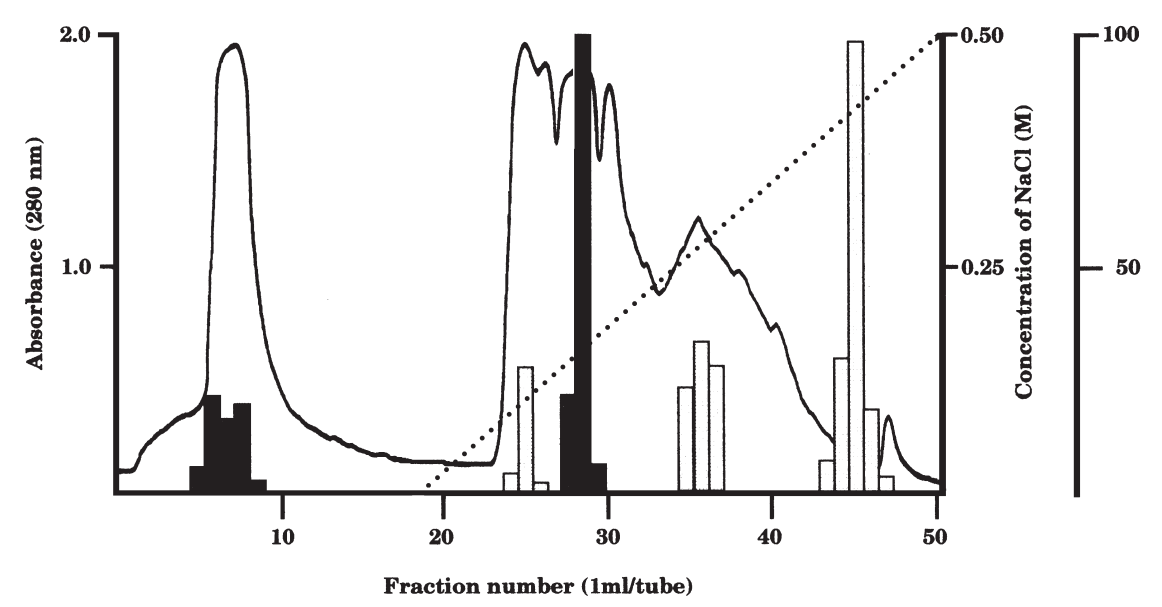

Fig. 1. Anion exchange chromatography (Mono Q) profile of $36 \mathrm{~h}$ incubation medium of the nematobacterial complex (NIM). Cytolytic activity (black bars) and unsticking activity (white bars) were expressed as the percentages of cells on monolayers. ( gradient of $\mathrm{NaCl}$; for details see Section 2 . 

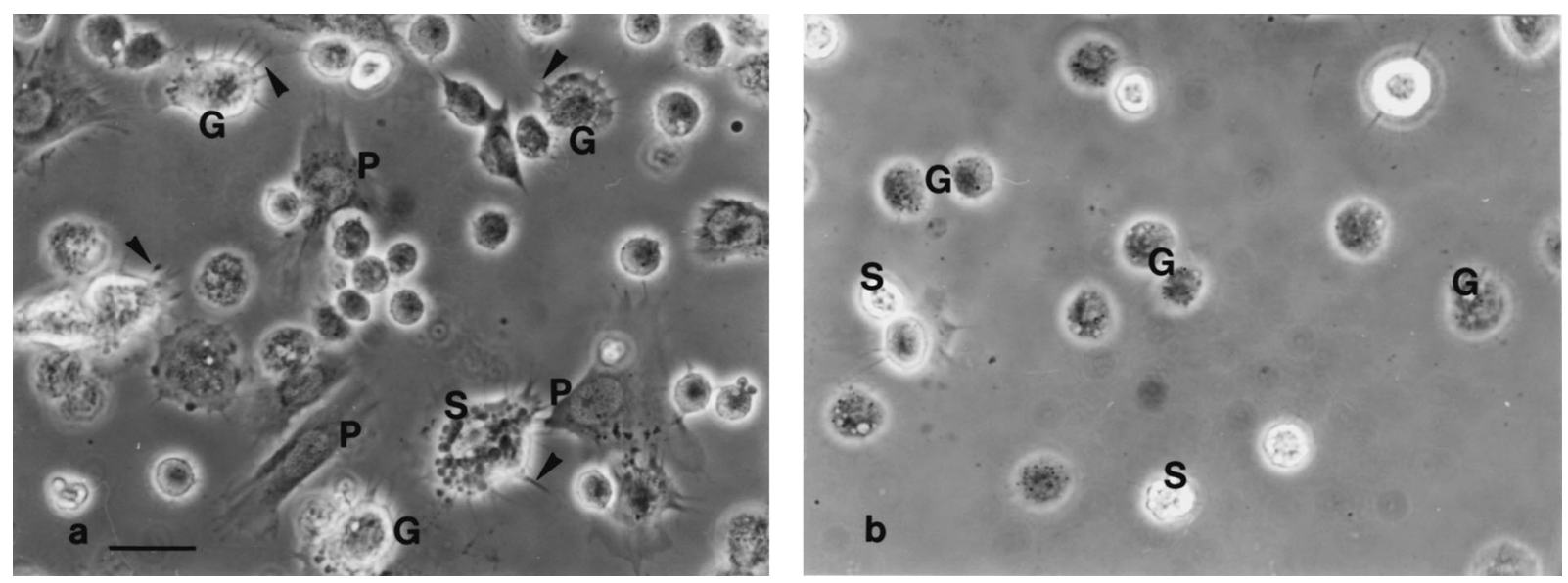

Fig. 2. Unsticking effects of the UnA fractions from MonoQ chromatography. Haemocyte monolayers were incubated for $1 \mathrm{~h}$ in MonoQ fractions (dilution $1 / 2$ in PBS). a. control; b. UnA fractions. In control, plasmatocytes (P) were extensively spread on the coverslip and most granular haemocytes (G) and spherule cells (S) have developed filopodia (arrowheads). After incubation with UnA (b), most plasmatocytes have disappeared and the remaining granular haemocytes and spherule cells have lost their filopodia. (bar=12 $\mu \mathrm{m}$ ).

with unsticking activity were tested on monolayers, the haemocytes became rounded whatever their type, after 30-45 min incubation. After 30 min more of incubation, numerous cells were detached from the coverslip and fell to the bottom of the well. Most of these cells were plasmatocytes whereas most of the cells remaining on the coverslip (top of the incubation chamber, Fig. 2b) were granular haemocytes (Table 2). Up to $98 \%$ and $95 \%$ of haemocytes (the free and the adhesive cells) after $30 \mathrm{~min}$ or one hour incubation respectively, were not stained with Trypan Blue and were considered as living cells.

\subsection{Lysis of haemocytes}

The amount of dead cells after incubation was proportional (i) to the concentration of NIM (Table 1) or of the CyA fractions (Table 3) and (ii) to the duration of incubation (Table 4) for a same concentration. Fractions preceding or following immediately the CyA ones in MonoQ chromatography had no effect on haemocytes in

\section{Table 2}

Effect of unsticking factor from MonoQ (dilution 1:1 in PBS) on different types of haemocytes in function of time

\begin{tabular}{lll}
\hline Time (min) & $\begin{array}{l}\text { Unstuck cells } \\
\text { Granulocytes }\end{array}$ & Plasmatocytes \\
\hline Initial & $0.3 \pm 0.03$ & $0.4 \pm 0.03$ \\
30 & $11.3 \pm 5.8$ & $26.0 \pm 12.1$ \\
45 & $15.2 \pm 4.7$ & $32.5 \pm 13.2$ \\
60 & $20.1 \pm 3.1$ & $61.7 \pm 8.1$ \\
Controls $^{\mathrm{b}}$ at $60 \mathrm{~min}$ & $<2$ & $<2$ \\
\hline
\end{tabular}

a In percent of total haemocyte of each type. Mean \pm Standard Deviation; $\mathrm{n}=30$ in three experiments.

b Fractions preceding and following the UnA ones in MonoQ chromatography.
Table 3

Sensibility of different haemocyte types of Mythimna unipuncta to cytolytic fractions $(\mathrm{CyA})$

\begin{tabular}{llll}
\multirow{2}{*}{$\begin{array}{l}\text { CyA dilutions } \\
\text { in PBS }\end{array}$} & \multicolumn{2}{l}{ Mortality $^{\mathrm{a}}$} & \\
\cline { 2 - 4 } & Granulocytes & Plasmatocytes & Spherule cells \\
\hline $1 / 2$ & 100 & 100 & 100 \\
$1 / 4$ & 100 & 100 & $60 \pm 8.8$ \\
$1 / 8$ & $67.3 \pm 9.3$ & $21.0 \pm 1.9$ & $3.3 \pm 0.1$ \\
$1 / 16$ & $20.1 \pm 1.1$ & $2.7 \pm 0.6$ & $<2$ \\
$1 / 32$ & $3.3 \pm 0.3$ & $<2$ & $\mathrm{NT}$ \\
$1 / 64$ & $<2$ & $<2$ & $\mathrm{NT}$ \\
$1 / 128$ & $<2$ & $<2$ & $\mathrm{NT}$ \\
Controls $^{\mathrm{b}}$ & $<2$ & $<2$ & $<2$ \\
\hline
\end{tabular}

a Cells stained with Trypan Blue, in percent of each haemocyte type. Mean \pm standard deviation; $n=10$. Incubation time : $1 \mathrm{hr}$. NT $=$ not tested.

b Fractions preceding or following the CyA ones in MonoQ chromatography (dilution 1:1 in PBS).

Table 4

Cytotoxicity of nematobacterial complex incubation medium ${ }^{\mathrm{a}}$ in function of time

\begin{tabular}{ll}
\hline Incubation time $(\mathrm{min})$ & Total haemocyte mortality ${ }^{\mathrm{b}}(\%)$ \\
\hline 15 & $3.0 \pm 1.8$ \\
30 & $31.4 \pm 2.2$ \\
45 & $77.7 \pm 3.1$ \\
60 & 100 \\
Control at $60 \mathrm{~min}$ & $<2$ \\
\hline
\end{tabular}

a Dilution: 1:4 in PBS.

b $\quad$ Mean \pm Standard Deviation; $\mathrm{n}=30$. 
monolayers (not shown). The haemocyte types did not exhibit the same sensibility to the cytotoxic factors, granular haemocytes being the most sensitive and spherule cells the least sensitive (Table 3). The morphology of the haemocytes after incubation, also depended on the dilution of solution. For instance, in a series of experiments the cells were observed after $1 \mathrm{~h}$ incubation in the following dilutions of a CyA fraction in PBS:

- at the highest dilutions (1/64 and more), haemocytes appeared as spreading cells not stained with Trypan Blue, as they were in control (Fig. 3a).

- after incubation at dilutions up to $1 / 16$, some haemocytes (especially granular haemocytes) appeared as rounded cells with vacuoles in the cytoplasm (Fig. 3b) and were stained with Trypan Blue. These vacuoles were located in the close vicinity of the nucleus suggesting a dilatation of the perinuclear cisterna. Other haemocytes (especially plasmatocytes) did not show these modifications, were not stained with Trypan Blue and were considered as living cells.

- at 1/8 dilution vacuoles were also evident in plasmatocytes which began to lose their lamellipodia (Fig. 3c)

- at 1/4 dilution, the number and size of intracytoplasmic vacuoles increased in all haemocytes (Fig 3d). Numerous haemocytes exhibited a pycnotic nucleus. Most haemocytes were dead cells, stained with Trypan Blue.

- at 1/2 dilution, all haemocytes appeared as rounded swollen cells (Fig. 3e) and it was difficult to distinguish plasmatocytes from granular haemocytes.

In some experiments, when NIM was used in place of the CyA fractions, at the lowest dilution (1/2) most haemocytes appeared as swollen cells and it was no longer possible to distinguish plasmatocytes from granular haemocytes. Some of these haemocytes seemed to have burst out and only appeared as naked nuclei surrounded by remnants of cytoplasm (Fig. 3f). All haemocytes were dead cells.

\subsection{Action of LPS}

LPS extracted from the bacteria recovered from the nematobacterial complex or LPS from Escherichia coli were used. When these LPS were added to control solutions, no unsticking or cytotoxic effect was observed. Moreover no enhancement of cytotoxic or unsticking activities was obtained when LPS were added to CyA or UnA fractions (not shown).

\subsection{First characterization of the UnA and CyA}

- Dialysis: both activities were retained after dialysis of the NIM for 24 hours against PBS. The membrane used retained proteins with a MW higher than $10^{4}$.

- Resistance to temperature: unsticking and cytotoxic effects were lost after $30 \mathrm{~min}$ incubation at $45^{\circ} \mathrm{C}$ or $1 \mathrm{~h}$ at $57^{\circ} \mathrm{C}$ respectively.

- Action of protease: after incubation for $30 \mathrm{~min}$ in a solution of trypsin (final concentration $4.10^{-6} \mathrm{M}$ ) at $37^{\circ} \mathrm{C}$, the lytic activity of CyA fractions was totally lost. Trypsin solution alone had no lytic activity against insect haemocytes at this concentration but it had an unsticking effect. So it was not tested on the UnA fractions.

\subsection{Tests for enzymatic activities}

- Lipase and lecithinase: These activities were present in NIM but none of these were observed in CyA or UnA fractions.

- Protease: In absence of incubation with nematobacterial complex, no proteolytic activity was detected in the control medium. The nematode incubation medium had a protease activity evidenced on azoalbu$\min$. The CyA fractions were negative for protease in the conditions of our experiments but the fractions with unsticking activity showed protease activity. Depending on the experiments, one or two other fractions from the Mono Q chromatography exhibited protease activity but a very weak unsticking effect. No lytic activity on haemocytes was observed in these fractions.

\subsection{Test for LPS (endotoxin)}

The Limulus test was positive when used with the native medium and the titre of activity slightly increased in NIM with incubation time. Depending on the experiments, low levels of activity were also detected in different fractions from anion exchange chromatography.

\section{Discussion}

The nematobacterial complex S. carpocapsae-X. nematophilus is highly pathogenic for numerous insect species and it is well known that this complex is able to evade or to depress insect immunity (Brehélin et al., 1989; Dunphy and Thurston, 1990). But the ways by which this evasion or this depression are achieved, are not understood. Different immune depressive activities of this complex have been demonstrated in vivo, such 

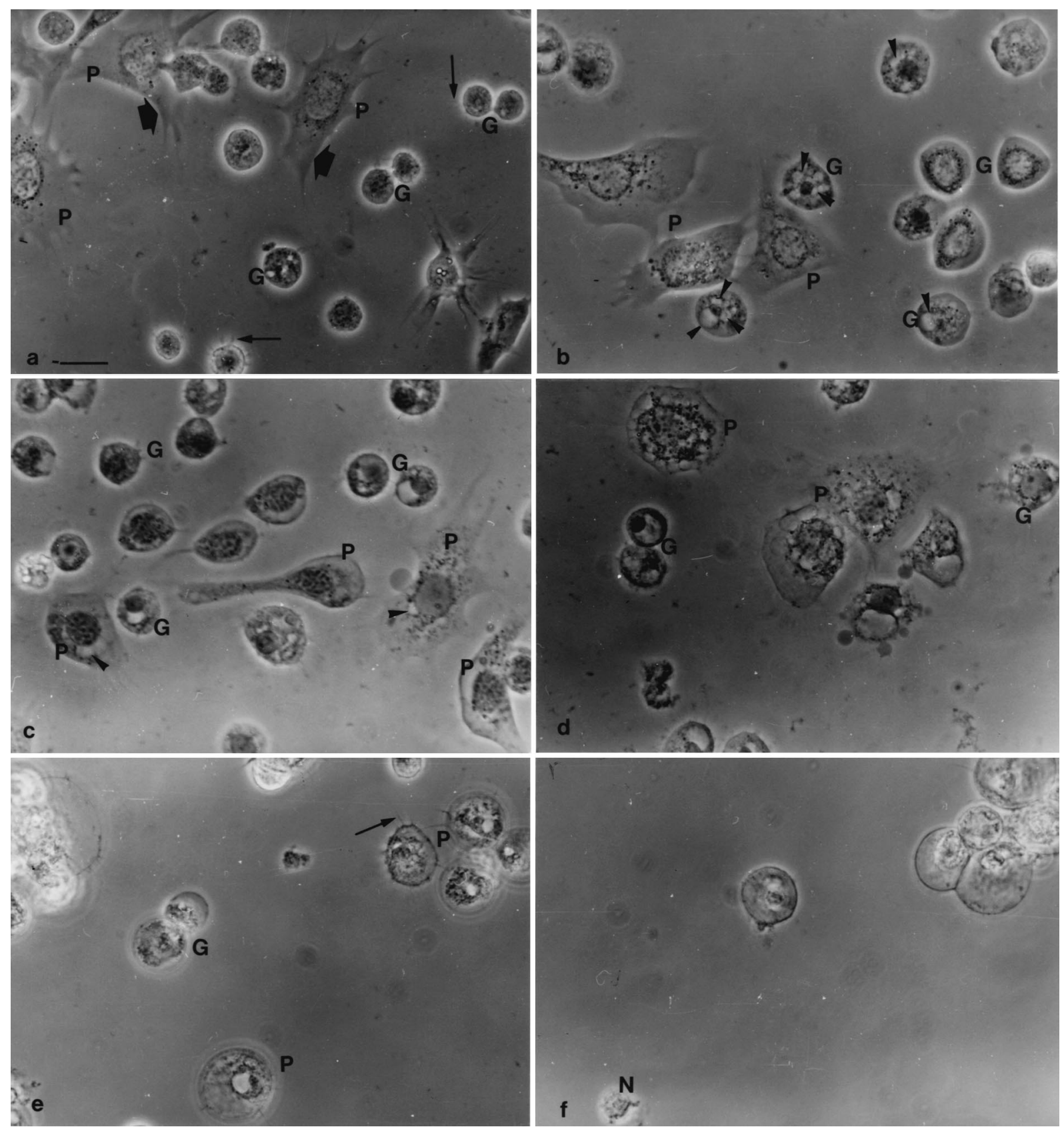

Fig. 3. Cytotoxic effects of NIM or CyA fractions from MonoQ chromatography. Haemocyte monolayers were incubated in the different media (see below) for $1 \mathrm{~h}$ and observed under phase contrast microscopy. All pictures are at the same magnification (bar=10 $\mu \mathrm{m}$ ). a. Control: incubation in sterile native medium ( $\mathrm{CM}=$ control medium, not incubated with the nematobacterial complex) at dilution of $1 / 2$ in PBS. Note the spreading of plasmatocytes (P) with large lamellipodia (large arrows). Granular haemocytes (G) were rounded cells with thin filopodia (thin arrows). b. incubation in fraction with cytotoxic activity (CyA) from MonoQ chromatography of NIM, diluted 1/16 in PBS. Arrowheads: vacuoles in the granular haemocytes. Note that these vacuoles are in contact with nucleus. c. incubation in same fractions as in b., diluted 1/8 in PBS. Arrowheads: vacuoles in the plasmatocytes. d. incubation in same fraction at dilution 1/4. e.: dilution 1/2 of the CyA fraction: all haemocytes were swollen cells. Arrow: remnants of filopodia. f. dilution of NIM in PBS (1/2). Most haemocytes were swollen cells. N: naked nucleus, remnant of haemocytes. Note that haemocytes were less numerous than in other pictures, due to the unsticking effect of NIM. (For details see text).

as (i) haemocyte suppression (Dunphy and Thurston, 1990), (ii) inhibition of the antibacterial peptides produced by the insect (Götz et al., 1981) and (iii) suppression of the phenoloxidase activity (Brehélin et al., 1989; Dunphy and Webster, 1991). The anti-antibacterial peptide activity (disappearence of the antibacterial peptides) was assigned to a protease secreted by the nematode (Götz et al., 1981) but the factors responsible for the other effects are still unknown. As in vitro assays were lacking, most of the studies on the pathogenicity of this complex have been performed in vivo. This did not allow an easy quantification of the observed effects 
and complicated significantly the purification of the factors involved. In fact, even in the case of enzymatic activities that can be tested in vitro, none of the responsible factors has already been fully purified from $S$. carpocapsae or X. nematophilus (Kucera and Mracek, 1989; Akhurst and Dunphy, 1993) with exception of a lecithinase from X. nematophilus (Thaler et al., 1998). Proteases were characterized from a related bacteria species Photorhabdus luminescens (Schmidt et al., 1988; Thai et al., unpublished results) which has a symbiotic relationship with entomopathogenic nematodes of the family Heterorhabditidae.

In all our experiments, controls showed that the bacteria associated to holoxenic nematodes were X. nematophilus.

In the present study we show that, in course of in vitro incubation of the nematobacterial complex, different factors such as unsticking and cytotoxic factors were present in the medium. From our study it appears that factors with unsticking effect were produced mainly by the nematode but bacteria also produced factors with unsticking activity and these were eluted with the same percentage of $\mathrm{NaCl}$ in MonoQ chromatography. Studies are in course to compare the unsticking factors of nematodes to those of bacteria. The cytotoxic factors seem to be produced by the bacteria. This is in accordance with previous results (Givaudan et al., unpublished work). Furthermore we show that (i) the haemocytes are one of the targets of these factors in vitro, (ii) these factors could be separated from each other by a single chromatographical step, (iii) these factors generate different effects on the target cells (iv) these effects can be quantified. We also show that the cytotoxic effect was time and dose dependent. All this demonstration is now leading us to the purification and characterization of the molecules involved.

Different strains of $X$. nematophilus and P. luminescens have been shown to produce proteases, lipase and lecithinase after growth in medium (Akhurst, 1980; Bleakly and Nealson, 1988; Boemare and Akhurst, 1988; Schmidt et al., 1988). In our experiments too, lipase, lecithinase and protease were produced during incubation of the nemato-bacterial complex. However these enzymatic activities were not recovered in the CyA fractions; protease activity was present in the fractions with unsticking effect. Proteases such as trypsin are generally used to release adhering cells from culture flasks. Thus the unsticking effect detected in fractions from anion exchange chromatography in the present work, could be correlated to the protease activity of these fractions. On the other hand, as no protease, lipase or lecithinase activities were detected in the CyA fractions, the cytotoxic activity does not seem to be borne by any enzyme of these kinds.

It is well known that LPS, released by Gram negative bacteria, induce a range of pathophysiological reactions in vertebrates. But endotoxin exerts its biological effects by the stimulation of production and release of endogenous mediators such as Interleukin or Tumor Necrosis Factor and not by a direct toxicity on the host cells (Schletter et al., 1995). In insects infected by X. nematophilus, LPS have been shown to be released and to have a direct toxic effect on haemocytes (Dunphy and Webster, 1988). As this cytotoxic effect was observed in vivo, it is not possible to compare this result to those reported here. For Goldenberg et al. (1984), LPS have toxic effects on lobster haemocytes in vitro when used at concentrations higher than $10 \mu \mathrm{g} / \mathrm{ml}$. Aono et al. (1994) observed a cytotoxic effect induced by LPS on lobster hyaline and semi-granular haemocytes in vitro, only when extract of granular haemocytes were added to the LPS solution. On the other hand, for Charalambidis et al. (1995) solutions of LPS, up to $500 \mu \mathrm{g} / \mathrm{ml}$, had no toxic effect on insect haemocytes in vitro. In our experiments, all the controls led us to the conclusion that the factors responsible for the cytolysis were proteic rather than lipopolysaccharidic in nature: (i) no lytic activity on haemocyte monolayers of the different LPS solutions tested, (ii) limulus test positive in different chromatographic fractions tested, even in those with no cytotoxic activity, (iii) sensitiveness of the active fractions to temperature and to protease.

The two factors presented in this study (CyA and UnA) are active on the insect immunocompetent cells, the haemocytes. If these factors are produced in insects in the course of a normal infection by the nematobacterial complex, they could be involved in the infectious process by depression of some of the immune reactions. As the activities of the factors were different from each other, the immune depression could be achieved by addition of the different effects. Proteins which lysed haemocytes (CyA) could lower the number of cells available for two major immune reactions, encapsulation and phagocytosis. Factors with unsticking effect (UnA) could lower or suppress the ability of haemocytes to stick to each other and not allow the formation of capsules around nematodes or of nodules around bacteria.

Concerning the cytotoxic effect (CyA), we show here that sensitiveness of $M$. unipuncta haemocytes was dependent on the cell type. Granular haemocytes, haemocytes with the most endocytic capabilities (Ribeiro et al., 1996) were more sensitive than plasmatocytes which are the cells endowed with capsule formation. On the other hand, the unsticking factors were more active on plasmatocytes than on granular cells. This suggests a specificity for the molecules involved and the reason of this specificity is now under study.

\section{Acknowledgements}

We thank Dr O. Thaler for tests of lipase and lecithinase and M. P.A. Girard for technical assistance. 
This work was supported by grants 2167 and 3356 from Centre National de la Recherche Scientifique (France) and Junta Nacional de Investigaçao Cientifica e Tecnologica (Portugal) and by a grant fellowship to C.R. from Action de Cooperation Scientifique et Technique 819 from the European Community.

\section{References}

Akhurst, R.J., 1980. Morphological and functional dimorphism in Xenorhabdus spp., bacteria symbiotically associated with the insect pathogenic nematodes Neoplectana and Heterorhabditis. Journal of General Microbiology 121, 303-309.

Akhurst, R.J., Dunphy, G.B., 1993. Tripartite interactions between symbiotically associated entomopathogenic Bacteria, Nematodes and their Insect hosts. In: Beckage, N.E., Thompson, S.N., Federici, B.A. (Eds.), Parasites and Pathogens of Insects, Vol. 2. Academic Press, San Diego, pp. 1-23.

Aono, H., Gomez Diaz, G., Mori, K., 1994. Granular cells recognize non-self signals and trigger the clotting reaction of hemocytes in vitro in the spiny lobster Panulirus japonicus. Comparative Biochemistry and Physiology 107A, 37-42.

Bleakly, B., Nealson, K.H., 1988. Characterization of primary and secondary forms of Xenorhabdus luminescens strain Hm. FEMS Microbiology Ecology 53, 241-250.

Boemare, N., Akhurst, R.J., 1988. Biological and physiological characterization of colony form variants in Xenorhabdus spp. Journal of General Microbiology 134, 751-761.

Boemare, N., Akhurst, R.J., Luciani, J., 1982. Mise en évidence d'une toxicogénèse provoquée par le nématode axénique entomophage Neoplectana carpocapsae. Comptes Rendus de l'Académie des Sciences Paris 295, 543-546.

Boemare, N., Thaler, J.O., Lanois, A., 1997. Simple bacteriological tests for phenotypic characterization of Xenorhabdus and Photorhabdus phase variants. Symbiosis 22, 167-175.

Boemare, N., Bonifassi, E., Laumond, C., Luciani, J., 1983. Etude expérimentale de l'action pathogène du nématode Neoplectana carpocapsae Weiser; recherches gnotobiologiques chez l'insecte Galleria mellonella $\mathrm{L}$. Agronomie 3, 407-415.

Bowen, D., Rocheleau, T.A., Blakburn, M., Andreev, O., Golubeva, E., Bhartia, R., Ffrench-Constant, R.H., 1998. Insecticidal toxins from the bacterium Photorhabdus luminescens. Science 280, 2129-2131.

Brehélin, M., Drif, L., Baud, L., Boemare, N., 1989. Activation of prophenoloxidase in Insect haemolymph: cooperation between humoral and cellular factors in Locusta migratoria. Insect Biochemistry 19, 301-307.

Brunham, R.C., Plummer, F.A., Stephens, R.S., 1993. Bacterial antigenic variation, host immune response and pathogen-host coevolution. Infection and Immunity 61, 2273-2276.

Burman, M., 1982. Neoplectana carpocapsae: Toxin production by axenic parasitic nematodes. Nematologica 28, 62-70.

Charalambidis, N.D., Zervas, C.G., Lambropoulou, M., Katsoris, P.G., Marmaras, V.J., 1995. Lipopolysaccharide-stimulated exocytosis of nonself recognition protein from insect hemocytes depend on pro- tein tyrosine phosphorylation. European Journal of Cell Biology 67, 32-41.

Dunphy, G.B., Thurston, G.S., 1990. Insect Immunity. In: Gaugler, R. Kaaya, H.K. (Eds.), Entomopathogenic Nematodes in Biological Control. CRC Press, Boca Raton, pp. 301-323.

Dunphy, G.B., Webster, J.M., 1991. Antihemocytic surface components of Xenorhabdus nematophilus var. dutki and their modification by serum of nonimmune larvae of Galleria mellonella. Journal of Invertebrate Pathology 58, 40-51.

Dunphy, G.B., Webster, J.M., 1984. Interaction of Xenorhabdus nematophilus subsp. nematophilus with the haemolymph of Galleria mellonella. Journal of Insect Physiology 30, 883-889.

Dunphy, G.B., Webster, J.M., 1988. Virulence mechanisms of Heterorhabditis heliothidis and its bacterial associate, Xenorhabdus luminescens, in non-immune larvae of the greater wax moth Galleria mellonella. International Journal of Parasitology 18, 729-737.

Goldenberg, P.Z., Huebner, E., Greenberg, A.H., 1984. Activation of lobster hemocytes for phagocytosis. Journal of Invertebrate Pathology 43, 77-88.

Götz, P., Boman, A., Boman, H.G., 1981. Interactions between insect immunity and an insect pathogenic nematode with symbiotic bacteria. Proceedings of the Royal Society London 212, 333-350.

Hoffmann, J.A., Reichhart, J.M., Hetru, C., 1996. Innate immunity in higher insects. Current Opinion in Immunology 8, 8-13.

Kucera, M., Mracek, Z., 1989. Partial purification and properties of proteolytic enzymes of steinernematid nematodes pathogenic for Galleria mellonella larvae. Acta Entomologica Bohemoslova 86, 342-348.

Laumond, C., Mauléon, H., Kermarrec, A., 1979. Données nouvelles sur le spectre d'hôtes et le parasitisme du nématode entomophage Neoplectana carpocapsae. Entomophaga 24, 13-27.

Mead, G.P., Ratcliffe, N.A., Renwrantz, L., 1986. The separation of insect haemocyte types on Percoll gradients: methodology and problems. Journal of Insect Physiology 13, 167-177.

Ni Eidhin, D., Mouton, C., 1993. A rapid method for preparation of rough and smooth lipopolysaccharide from Bacteroides, Porphyromona and Prevotella. FEMS Microbiology Letters 110, 133-138.

Ribeiro, C., Simöes, N., Brehélin, M., 1996. Insect Immunity: The haemocytes of the armyworm Mythimna unipuncta (Lepidoptera:Noctuidae) and their role in defence reactions. In vivo and in vitro studies. Journal of Insect Physiology 42, 815-822.

Schletter, J., Heine, H., Ulmer, A.J., Rietschel, E.T., 1995. Molecular mechanism of endotoxin activity. Archives of Microbiology 164, 383-389.

Schmidt, T.M., Bleakley, B., Nealson, K.H., 1988. Characterization of an extracellular protease from the insect pathogen Xenorhabdus luminescens. Applied and Environmental Microbiology 54, 2793-2797.

Sierra, G., 1957. A simple method for the detection of lipolytic activity of microorganisms and some observations on the influence of the contact between cells and fatty substrates. Antonie van Leeuwenhoek $23,15-22$.

Thaler, J.O., Duvic, B., Givaudan, A., Boemare, N., 1998. Isolation and entomotoxic properties of the Xenorhabdus nematophilus F1 lecithinase. Applied and Environmental Microbiology 64, 23672373.

Vieira, V., Pintureau, B., 1994. Comparaison biologique de trois populations de Mythimna unipuncta originaire de trois îles des Açores. Boletim da Sociedade Portuguesa de Entomologia 12, 301-312. 